\title{
Adocus Kohaku, A New Species of Aquatic Turtle (Testudines: Cryptodira: Adocidae) from the Late Cretaceous of Kuji, Iwate Prefecture, Northeast Japan, with Special References to the Geological Age of the Tamagawa Formation (Kuji Group)
}

\section{LSID urn:Isid:zoobank.org:act:61376EEE-A386-416E-98AE-FF64FE2597A2}

\author{
Ren Hirayama ${ }^{1 *}$, Teppei Sonoda ${ }^{2}$, Hikaru Uno ${ }^{3}$, Kenji Horie ${ }^{4}$, Yukiyasu \\ Tsutsumi ${ }^{5}$, Kazuhisa Sasaki ${ }^{6}$, Shunsuke Mitsuzuka ${ }^{7}$ and Toshio Takisawa ${ }^{8}$ \\ ${ }^{1}$ School of International Liberal Studies, Waseda University, Japan \\ ${ }^{2}$ Fukui Prefectural Dinosaur Museum, Japan \\ ${ }^{3}$ Research Institute for Science and Engineering, Waseda University, Japan \\ ${ }^{4}$ Geoscience Group, National Institute of Polar Research, Japan \\ ${ }^{5}$ Department of Geology and Paleontology, National Museum of Nature and Science, Japan \\ ${ }^{6}$ Kuji City Office, Japan \\ ${ }^{7}$ Nippon Koei Co., Ltd., Japan \\ ${ }^{8}$ Kuji Amber Museum, Japan
}

*Corresponding author: Ren Hirayama, School of International Liberal Studies, Waseda University, Nishiwaseda 1-6-1, Shinjuku-ku, Tokyo 169-8050, Japan, Email: renhirayama@gmail.com

\section{Abstract}

A nearly complete shell of the genus Adocus (Adocidae; Pan-Trionychia; Cryptodira; Testudines) was collected from the late Cretaceous (Turonian) Tamagawa Formation of Kuji Group at Kuji City, Iwate Prefecture, northeast Japan. This turtle shows unique features such as the loss of cervical scute, extreme expansion of marginal scutes overlying costal plates, and exclusion of the humeral- pectoral sulcus from entoplastron. Thus, $A$. kohaku is erected as a new species. As $A$. kohaku shows most derived position of $A$. kohaku within this genus, morphological diversity of the genus Adocus seems to have occurred rather early in its evolution in Eastern Asia.

Keywords: Adocus Kohaku sp. nov.; Cretaceous; Kuji Group; Reptilia; Testudines; U-Pb Dating

Institutional Abbreviation: KAM: Kuji Amber Museum; NIPR: National Institute of Polar Research; NMNS: National Museum Nature and Science; RH: Ren Hirayama.

\section{Introduction}

Kuji City of Iwate Prefecture, northeastern Japan has been well known as a rich source of ambers since the Neolithic era [1]. Recently, highly diverse vertebrate fauna, including more than 2000 isolated bones and teeth of turtles, crocodylomorphs and some dinosaurs, has been excavated from the upper part of the Tamagawa Formation of the Kuji Group of Kuji City [2-12].

Palynological analysis from this bone bed of the Tamagawa Formation suggests a fluvial depositional environment under a warm climate with humid conditions [13]. 


\section{International Journal of Paleobiology \& Paleontology}

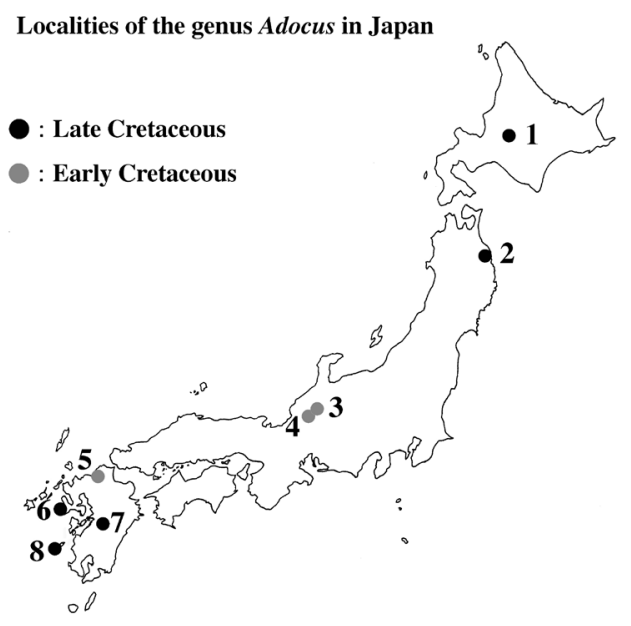

Figure 1: Localities of the genus Adocus in Japan. 1, Adocus sp. from Cenomanian of Mikasa, Hokkaido Prefecture [21]; 2, Adocus kohaku sp. nov. from Turonian of Kuji, Iwate Prefecture; 3, Adocus sp. from Aptian of Hakusan, Ishikawa Prefecture [22]; 4, Adocus sp. from Aptian of Katsuyama, Fukui Prefecture [18,19,23]; 5, Adocus sengokuensis from Barremian of Miyawaka, Fukuoka Prefecture [19]; 6, Adocus sp. from Santonian or Campanian of Nagasaki, Nagasaki Prefecture [24]; 7, Adocus sp. from Santonian? of Mifune, Kumamoto Prefecture [25]; 8, Adocus sp. from Campanian of Koshikijima, Kagoshima Prefecture [26].

Fossil locality and geological map of the Kuji Group (after Hirayama et al., 2010)

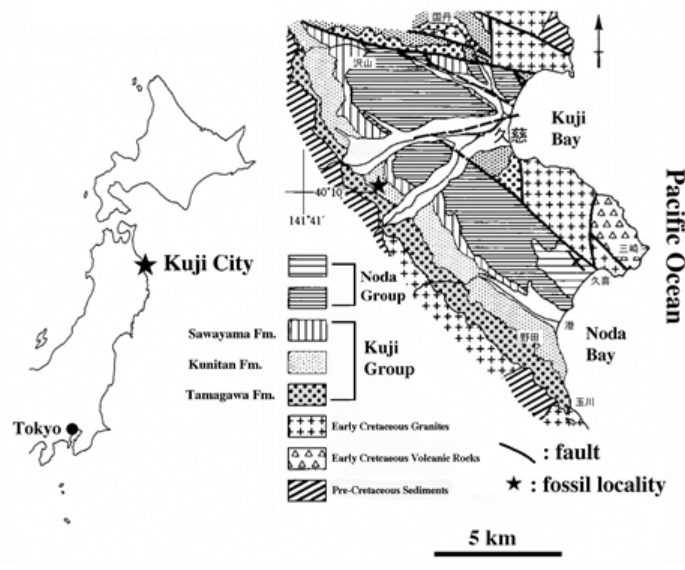

Figure 2: Fossil locality of Adocus kohaku sp. nov., and geological map of the Kuji Group [2,3].

Among fossil vertebrates from the Tamagawa Formation, shell materials of fresh water turtles such as trionychids (Trionychidae) and the genus Adocus (Adocidae) are most abundant $[8,9]$. Species of Adocus were common non- marine turtles of Asia and North America from the early Cretaceous to Paleogene [14-17]. In Japan, this genus is also an abundant non-marine turtle in Early to Late Cretaceous sediments (Figure 1) [18,19], although most of materials are disarticulated shell elements. We here report on a new species of the genus Adocus based on a nearly complete shell and additional specimens from the Tamagawa Formation. All fossil materials are housed in the Kuji Amber Museum. Type specimen (KAM 01) was collected by Hirayama R, Sasaki K, Sonoda T and Shikama K, August 2008.

In addition, we revise the age of the bone bed based on zircons retrieved from the tuff bed overlaying the bone bed by using $\mathrm{U}-\mathrm{Pb}$ dating method [20].

\section{Geological Setting}

The Kuji Group is distributed from the downtown area of Kuji City and neighboring Noda Village in the northeastern part of Iwate Prefecture, Japan. The central part of the Upper Cretaceous Kuji Group in the Kuji district appears as a band extending in a north-south direction, which is around 15 $\mathrm{km}$ in length and around $2 \mathrm{~km}$ in width, stretching from the northwest to the southeast (Figure 2) [2,3]. The Kuji Group tilts to the east towards the Pacific Ocean at 10-20 degrees and creates a half-basin structure [27]. This group is subdivided into three formations, Tamagawa, Kunitan, and Sawayama formations, in ascending order. $[9,28]$.

The Tamagawa Formation was deposited from a terrestrial to shallow marine environment, and the faces are mostly made from conglomerate and siltstone. This formation is about $200 \mathrm{~m}$ thick and divided into three lithological parts. The lowest part is composed mainly of conglomerate, with beds of tuff, siltstone, and sandstone. The basal part is characterized by mudstone in reddish color. This reddish bed was exposed along the coastline of Noda-mura by the tsunami of 2011 [9]. The middle part of the bed is made of greenish sandstones and alternating layers of conglomerate and sandstone where amber and oyster bearing beds are found [29]. The highest part is comprised of conglomerate and sandstone as well as amber- rich and tuff intercalated siltstone.

The bone bed from which the specimen in this study was excavated, is located at the highest part of the Tamagawa Formation. A U-Pb dating of the volcanic ash overlying the bone bed comes to $90.51 \pm 0.54 \mathrm{Ma}$, which indicates that the upper part of the Tamagawa Formation is Turonian [20]. The lenticular tuff bed overlays the bone bed without significant hiatus.

The tuff bed forms a lenticular shape with approximately $10 \mathrm{~m}$ length along the river stream and $70 \mathrm{~cm}$ at maximum 


\section{International Journal of Paleobiology \& Paleontology}

thickness (Figure 3). The tuff bed does not have allochthonous sand and eroded plant litter, meaning that although the tuff is a lenticular deposit, it is not secondarily deposited by stream migration but part of an autochthonous tuff bed from volcanic ash fall (Mitsuzuka, Master thesis).

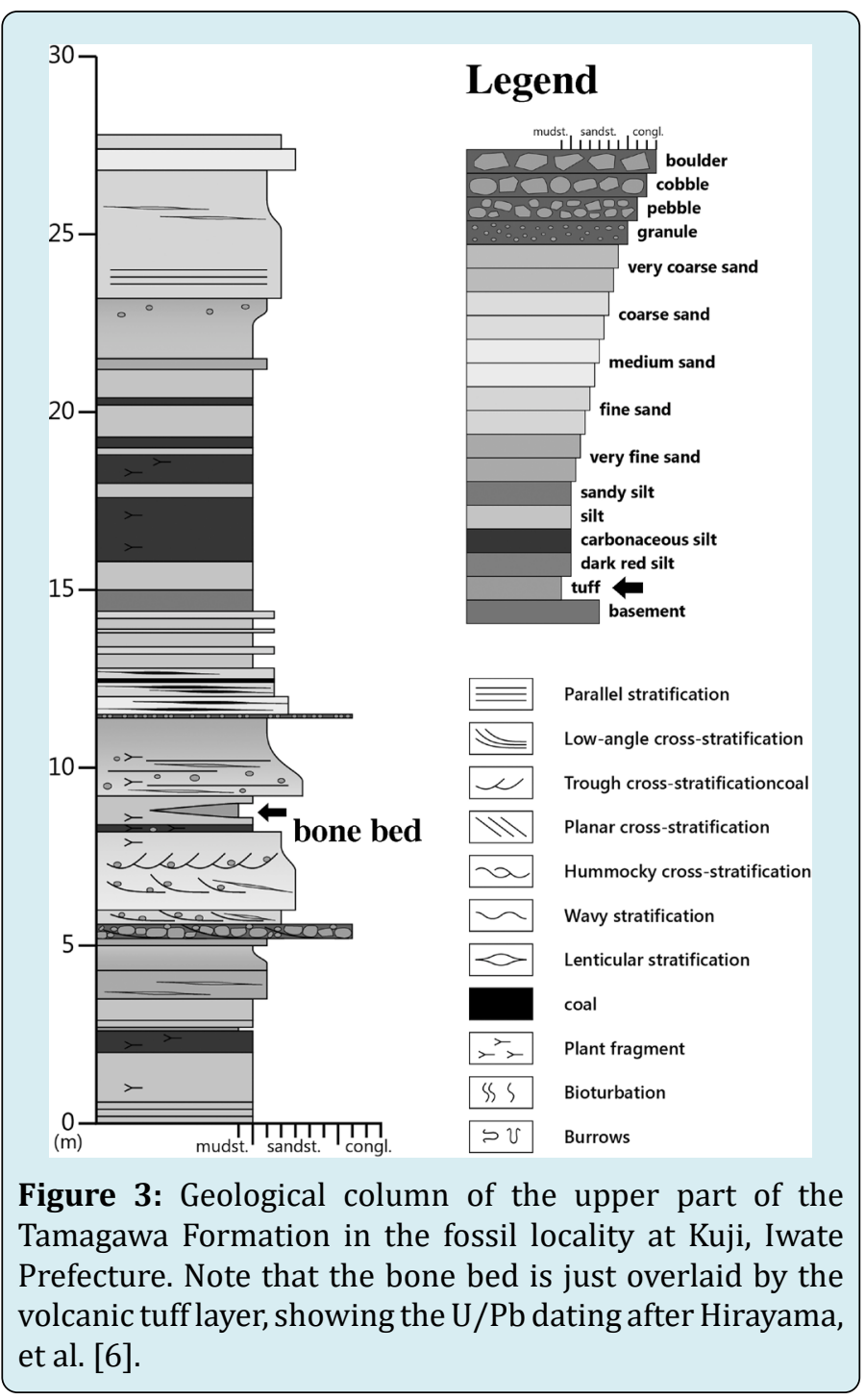

\section{Age of the Bone Bed in Previous Works}

The bone bed from which the specimen in this study was excavated is conformably overlaid by a tuff bed in the outcrop of the tributary of the Osawada River (Figure 2). To date, different ages have been suggested for this bed [9,30,31] (Table 1). We emended the age of the bone bed based on the zircon of the tuff bed by using U-Pb dating method. The $\mathrm{U}-\mathrm{Pb}$ dating is a widespread age-determination method for geological materials that depends on the accumulation of stable isotopes of $\mathrm{Pb}\left({ }^{206} \mathrm{~Pb}\right.$ and $\left.{ }^{207} \mathrm{~Pb}\right)$ by radioactive decay of $\mathrm{U}\left({ }^{235} \mathrm{U}\right.$ and $\left.{ }^{238} \mathrm{U}\right)$. The method has been often applied the zircon, $\mathrm{ZrSiO}_{4}$ in chemical formula. Zircon is very resistant to physical and chemical weathering within a closed system and very common in volcanic ash. In addition, zircon crystals concentrate $\mathrm{U}$ but discriminate against $\mathrm{Pb}$ during their formation, resulting in high ratio of $\mathrm{U} / \mathrm{Pb}$. The two distinct decay chains $\left({ }^{235} \mathrm{U}-{ }^{207} \mathrm{~Pb}\right.$ and $\left.{ }^{238} \mathrm{U}-206 \mathrm{~Pb}\right)$ are useful for obtaining an accurate age because of the coexistence of their own decay rates. Each decay chain individually expresses the age, as the two U-Pb decay chains independently results in a continuous change with time. Based on the features, the "concordia diagram" was introduced in order to verify whether the dual decay chains evolve within a closed system. The data of $\mathrm{U}-\mathrm{Pb}$ dating are on the concordia line, meaning that the $235 \mathrm{U}-207 \mathrm{~Pb}$ age equals the $238 \mathrm{U}-206 \mathrm{~Pb}$ age. indicating no effect of the loss and gain of $\mathrm{Pb}$ or $\mathrm{U}$.

\section{Materials and Methods}

A nearly complete shell (KAM 01; Figure 3 ) was collected by Sasaki, Hirayama, Sonoda, and Shikama from the amber collecting site nearby the Kuji Amber Museum in August of 2008. The occurrence of KAM 01 was briefly reported in an assemblage of semi-articulated shell elements in Hirayama, et al. [2,3]. KAM 01 was prepared by mechanic method. Additional materials were found from 2012 to 2019 from same locality, including KAM 16, another partially articulated specimen (Figure 4A).

\section{Zircon Extraction}

We sampled several hundred grams of tuff from the field. Zircon grains were extracted from the tuff sample by the following standard method; 1) crushing the tuff sample into the fine powder ( $<2.0$ micrometer), separating zircons by panning in water, 3) removing heavy minerals other than zircon by heavy-liquid method, 4) removing magnetic mineral by using neodymium magnet, 5) sorting out zircon grains by hand-picking under microscope, 6) molding handpicked zircon in epoxy resin and polishing to a middle crosssection of the height, 7) determining the analysis point based on the Cathodoluminescence imaging of zircon crystals. These procedures were conducted on NIPR and NMNS.

\section{Sensitive High-Resolution Ion Microprobe (SHRIMP)}

SHRIMP is an important tool for geologic materials. It is a high precision secondary ion mass spectrometer (SIMS) and makes in situ isotopic and chemical surface analysis of solid targets by bombarding the sample with an ion beam with 10 $30 \mu \mathrm{m}$ in diameter. SHRIMP is used for U-Pb geochronology, stable isotope analysis, trace element analysis.

Several Standard Reference were used; TEMORA2 (U$\mathrm{Pb}$ value; $416.8 \pm 0.3 \mathrm{Ma}$ ), OT4 (U-Pb value; $191.1 \pm 0.3 \mathrm{Ma})$ : 


\section{International Journal of Paleobiology \& Paleontology}

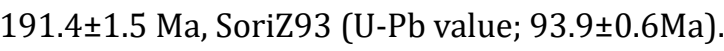

These ratios of $\mathrm{U}-\mathrm{Pb}$ were known were used for correction $\mathrm{U}-\mathrm{Pb}$ data.

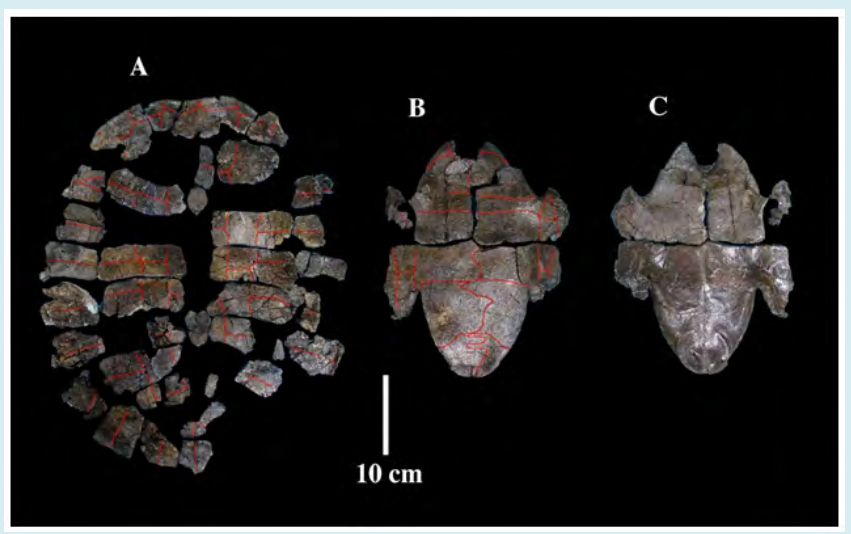

Figure 4: Turtle shell of Adocus kohaku sp. nov., holotype, KAM 01. A, carapace in dorsal view; B, plastron in ventral view; C, plastron in dorsal view. Red lines show scute sulci on shell surface.

\section{Comparative Materials}

Taxa of the genus Adocus from the Early Cretaceous of Japan such as A. sengokuensis Sonoda, et al. [19], and from the Late Cretaceous such as A. amtgai were examined for comparison.

\section{Systematic Paleontology}

Testudines Batsch, 1788

Cryptodira Cope, 1868

Pan-Trionychia Hummel, 1929

Adocidae Cope, 1870

Type Genus. - Adocus Cope, 1868

Known Distribution. - Early Cretaceous to Eocene of Asia and Late Cretaceous to Paleocene of North America.

Emended Diagnosis. - Thoracic rib heads of costals highly reduced; attachment area of xiphiplastron for pelvic girdle enlarged, forming semicircular concavity and rim; midline plastral scute sulcus sinuous.

\section{Genus Adocus Cope, 1868}

Type Species. -Adocus beatus (Leidy, 1865)

Known Distribution. - Early Cretaceous to Eocene of Asia and Late Cretaceous to Paleocene of North America.

Emended Diagnosis. - Fifth to eleventh marginal scutes medially enlarged, overlying distal portion of costal plates.

\section{Adocus kohaku, New Species}

Holotype. - KAM 01, a nearly complete shell (Figure 3). Type Locality. - Kokuji, Kuji, Iwate Prefecture, Japan. Type Horizon. - Tamagawa Formation, Kuji Group (Turonian, Late Cretaceous).

Etymology. - Named after Japanese name of amber as this fossil was associated with numerous ambers.

Diagnosis. - Adocus with cervical scute completely lost; fifth to tenth marginal scutes medially enlarged, overlying at least distal half of second to seventh costal plates; three pairs of inframarginals.

Referred Materials. - KAM 16, anterior portion of carapace (Figure 4A); OSD 249, right ninth peripheral (Figure 4C); OSD 520, entoplastron (Figure 4D); OSD 1901, partial carapace and plastron; OSD 1929, right third costal (Figure 4B); OSD 2278, right costal; OSD 2332, nuchal.

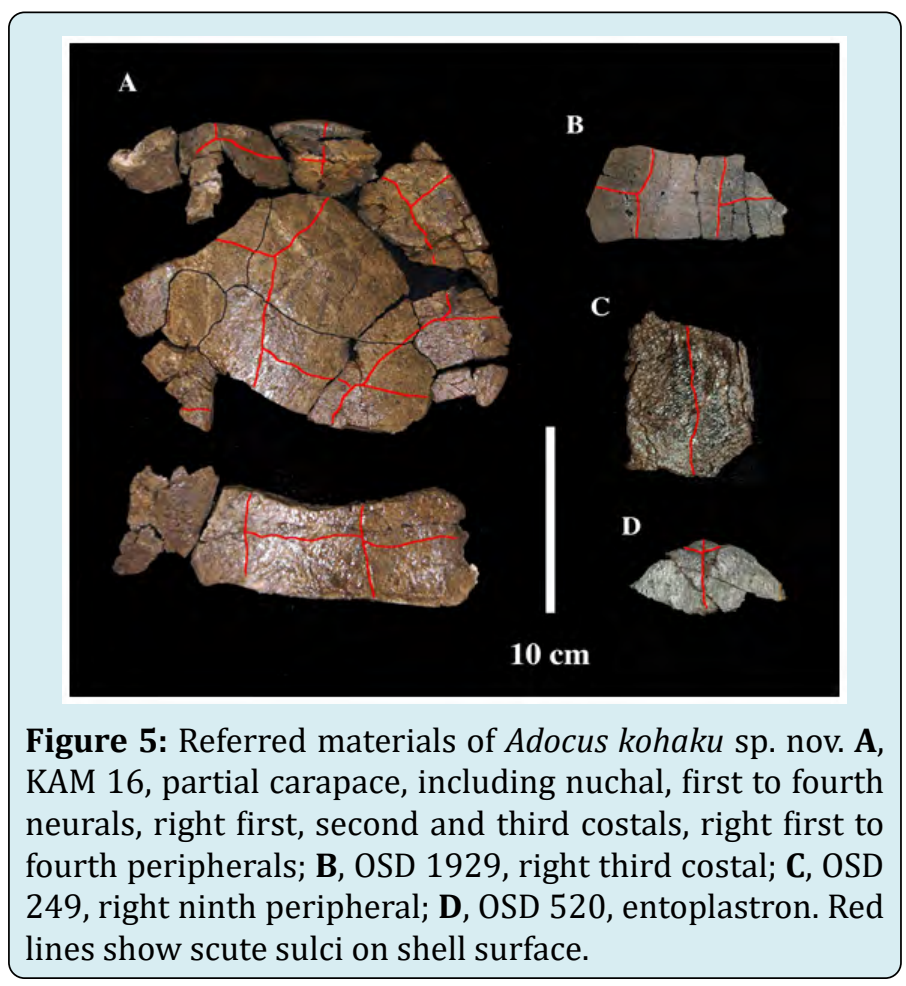

\section{Description}

\section{Shell (Figures 3 to 5)}

In KAM 01 (holotype of $A$. kohaku), both carapace and plastron are well preserved, but some neurals, costals, and peripherals are lost. The carapace is estimated to be about $45 \mathrm{~cm}$ long, whereas the plastron is $30 \mathrm{~cm}$ long as preserved in KAM 01. An isolated right ninth peripheral suggests a much larger individual with at least $60 \mathrm{~cm}$ long carapace are present (Figure 4C). The shell surface is covered by typical adocid sculpturing, consisting of relatively small and regular 


\section{International Journal of Paleobiology \& Paleontology}

grooves and pits.

Most of scute sulci are well preserved and clearly visible in KAM 01 and additional specimens. They, however, are extremely shallow as well as in the other Adocus species, only about 0.1 to $0.2 \mathrm{~mm}$ in depth, whereas living aquatic turtles with similarly sized shell, such as geoemydids, have the scute sulcus of at least $0.5 \mathrm{~mm}$ in depth (Hirayama, personal observation). Terrestrial turtles such as Testudinidae have the deepest scute sulcus. For instance, extant Manouria emys (RH 940; carapace $38 \mathrm{~cm}$ long) has the scute sulcus of $1.7 \mathrm{~mm}$ in depth. As the depth of scute sulcus is correlated with the thickness of the scale in extant turtles (Hirayama, personal observation), living Adocus should have had very thin scutes.

\section{Carapace}

The carapace is oval-shaped, widened slightly posteriorly, with a very shallow anterior emargination formed by the nuchal and anterior part of the first peripherals. The carapace seems low-domed, as in other Adocus, although it is difficult to see its exact nature due to the postmortem distortion.

The nuchal is a relatively wide hexagonal and slightly emarginated anteriorly in both KAM 01 and 16. Its free edge is rounded and upturned in the cross-section as well as in the first peripherals. The anterior border of the nuchal is relatively wide; the ratio of the anterior width of the nuchal to its maximal width is about seven-tenths, which is nearly identical with other Adocus. The anterolateral and posterolateral borders of the nuchal are nearly straight or slightly convex and about of the same length. As in other Adocus, the posterior border of the nuchal is concave and contacts with the first neural.

The neurals are represented by six elements; the third to fifth neurals are missing in KAM 01, whereas the first to fourth neurals are preserved in KAM 16. All neurals are longer than they are wide, and relatively thin and flat. The neural formula is typical of adocids: the first neural is hexagonal short-sided posteriorly, the second neural is rectangular, third to fifth neurals are hexagonal and short-sided anteriorly and the sixth neural is heptagonal in shape. The second neural of KAM 01 is very small, only about one half of the first neural in length. The seventh and eighth neurals seem absent, as in other Adocus.

There are two suprapygals in most species of Adocus, although only the second suprapygal is partially preserved in KAM 01.

The pygal is a slightly longer than wide, trapezoidal, and has straight lateral borders. The pygal morphology in KAM
01 is similar with that in other members of the Adocidae.

The costals are preserved, except for the left first and right second ones in KAM 01, whereas the right first, second and fourth costals are preserved in KAM 16. Ribheads of the costals are highly reduced and the ventral sides of costals are nearly flat as in other adocids. The seventh and eighth costals contact each other along the midline as in other Adocus.

The peripheral series is represented by the almost complete first to eleventh peripherals on the left side and the first to second, and fourth to eighth peripherals on the right side in KAM 01, whereas the first to third peripherals on the tight side are preserved in KAM 16. The free edges of the anterior peripherals (first to third) are upturned. The second and third peripherals on the left side seem fused together in KAM 01 as in the first and second peripherals in the second specimen of $A$. amtgai. The bridge peripherals (fourth to eighth) are mostly rectangular and seriously crushed in dorsal-ventral planes. The posterior peripherals (ninth to eleventh) are wider than the anterior ones with upturned free edges.

The cervical scute is completely absent on all nuchals (KAM 01, 16, and OSD 2332) of A. kohaku, whereas this scute is retained in other Adocus.

The first vertebral is trapezoidal, widened anteriorly and in contact with the second marginals, as in all other Adocus. The second to fourth vertebrals are longer than they are wide. The third vertebral seems longer than others. The fourth vertebral is constricted posteriorly, as in other Adocus. The fifth vertebral is possibly as small and ovate as in $A$. amtgai, although its exact outline is uncertain.

The pleurals are much longer than wide because of extreme expansion of the marginals onto the costals (Figure 5). The second to fourth pleurals are especially elongated proportionally, much narrower than the marginals on costals. In other Adocus, the pleurals are much wider than the marginals on the costals, or as wide as the marginals, as in A. amtgai (Figures 6 and 7).

The marginals are represented by a nearly complete set of scutes (12 pairs) on the left side in KAM 01. The first to third marginals are restricted to the peripherals and cover approximately half of their dorsal side. The fourth marginal overlaps onto the costals in KAM 16. The right fourth marginal overlaps the first costal only by its anteromedial part, whereas this scute overlaps the second costal by its posteromedial part in KAM 16. Thus, the overlapping of the marginals onto the costals begins with the fourth marginal as in A. aksary, A. amtgai, and A. inexpectatus. The fifth to tenth marginals overlap the corresponding costals (second 


\section{International Journal of Paleobiology \& Paleontology}

to eighth), covering at least one- third of their width as in $A$. amtgai. The seventh to tenth marginals cover the distal half of costals, much broader than pleurals on costals.

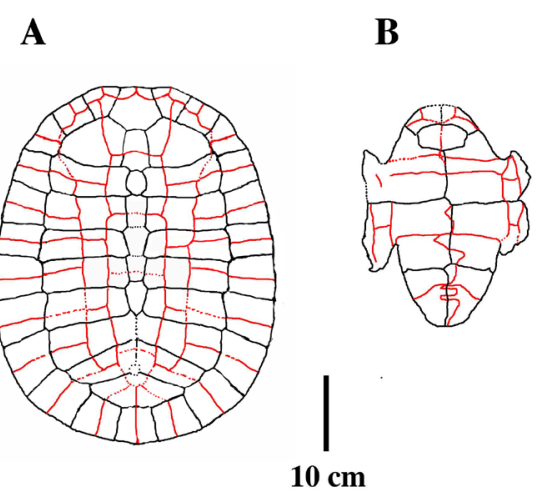

Figure 6: Shell restoration of Adocus kohaku sp. nov., largely based on KAM 01, with additions from KAM 16. Red lines show scute sulci on shell surface.

\section{Plastron}

The plastron is almost completely preserved in KAM 01 (Figures 4B and C). The anterior lobe of the plastron is wider than it is long (the length of the anterior lobe is about one half of its width), truncated anteriorly and does not reach the anterior carapace rim as in A. aksary and A. amtgai. The length of the anterior lobe makes up 30\% of the plastron length as in A. amtgai. The posterior lobe narrows posteriorly and is more acute than in other Adocus except for A. amtgai. The length of the plastral bridge is $40 \%$ of the plastron length. The gular and anal notches are absent as in other Adocus.

The epiplastron has a relatively wide and straight (truncated) anterior border, although the anteromedial area of epiplastra was broken during excavation. The dorsal surface of the epiplastron is concave.

The entoplastron is a large hexagonal element, much wider than it is long and with short lateral borders. The entoplastron of $A$. kohaku (KAM 01 and OSD 520) is shorter and wider than other species of Adocus.

The hyoplastra and hypoplastra have no peculiarities and make equal contributions to the bridge length. The left hyoplastron and the right hypoplastron have a long contact that separates the right hyoplastron from the left hypoplastron as in other Adocus.

The xiphiplastron is longer than it is wide, narrowed posteriorly and with a nearly straight lateral border as in
A. amtgai. The length of the xiphiplastron is $\sim 75 \%$ of the posterior lobe length along the midline. Internally, it bears a large semicircular depression and rim for the pelvic girdle. This unique structure was figured for Adocus from North America by Hay [32], and appears to be present in all adocids (Hirayama, pers. obs.)

The plastral scutes are represented by a complete set in KAM 01, including two pairs of gulars, extragulars, humerals, pectorals, abdominals, femorals, anals and three inframarginals.

The gulars are relatively wide, like in $A$. beatus and $A$. amtgai. The gulars are excluded the entoplastron in KAM 01, whereas they slightly cover the latter in OSD 520 as in most other species of Adocus. The extragulars are relatively small, covering about one-fourth of the external surface of the epiplastra, with short medial borders that comprise about three-fifths of length of the epiplastral symphysis as in $A$. beatus and $A$. amtgai, whereas in other species they are usually longer. The lateral borders of the extragulars are strongly elongated, reaching the epi-hyoplastral suture posteriorly as in

A. amtgai.

The pectorals are extremely shortened, slightly longer medially than laterally and excluded from the entoplastron. The pectorals of other species of Adocus are variable: overlapping (A. beatus, A. amtgai, "A." orientalis and A. inexpectatus) or not overlapping the entoplastron as in other species such as A. bossi from North America (Figure 8).

The abdominals are long and contribute to the rim of the inguinal notch. The femoral-anal sulcus is strongly sinuous.

The inframarginals are relatively narrow and restricted to hyo-hypoplastra as in other Adocus except for A. amtgai. There are only three inframarginals in KAM 01, whereas four inframarginals are usually found in most species of Adocus. The second inframarginal is much longer than others, spanning the hyo-hypoplastral suture. In other Adocus, the inframarginals are usually represented by four pairs, except for $A$. bossi which has three. The midline sulcus is strongly sinuous. The skin-scute sulcus lies close to the free edge of the plastral lobes.

\section{Discussion}

\section{Age of the Bone Bed}

Cathodoluminescence images of the zircon grains showed a rhythmic oscillatory pattern that showed the zircons were from igneous origin. As a result of $\mathrm{U}-\mathrm{Pb}$ dating, the ratio of ${ }^{206} \mathrm{~Pb} /{ }^{238} \mathrm{U}$ to ${ }^{207} \mathrm{~Pb} /{ }^{235} \mathrm{U}$ almost fit the concordant 


\section{International Journal of Paleobiology \& Paleontology}

curve. It showed preservation of closed system. The dating of each zircon grain mostly concentrated on a single cluster.
The U-Pb dating of lenticular tuff was $90.51 \pm 0.54 \mathrm{Ma}$

(MSWD=0.91).

Ages of the Bone Bed of Previous Studies

\begin{tabular}{|c|c|c|}
\hline Age & Material & Author \\
\hline $\begin{array}{c}\text { Boundary of Coniacian- Santonian } \\
\begin{array}{c}\text { From boundary between Coniacian-Santonian to } \\
\text { lower Campanian }\end{array}\end{array}$ & $\begin{array}{c}\text { palynostratigraphy U-Pb dating carbon } \\
\text { isotope excursion }\end{array}$ & Arimoto, et al. [30] \\
\hline Lower Coniacian & $\begin{array}{c}\text { Palynostratigraphy } \\
\text { Umetsu and Kurita [31] }\end{array}$ \\
\hline Lower to middle Santonian & $\begin{array}{c}\text { palynostratigraphy U-Pb dating carbon } \\
\text { isotope excursion }\end{array}$ & Arimoto, et al. [33] \\
\hline Upper Turonian & U-Pb dating & This study \\
\hline
\end{tabular}

Table 1: Comparison of the geological ages proposed for the bone bed of the Tamagawa Formation in previous research and this study.

Most previous studies considered the age of the bone bed ca. 86 Ma [31,34] (Table 2). These age inferences were commonly based on the palynostratigraphy. In the upper Tamagawa Formation of the Tamagawa Coast that might correlate to the bone bed, primitive and low-diverse Triprojectate pollens such as Aquilapollenites were found [9,31]. Triprojectates were index fossils expressing the border between Santonian and Coniacian ( $c a .86 \mathrm{Ma}$ ). Arimoto, et al. [34] also depended on this argument.

We, however, question the validity of the previous dating by palynostratigraphy. 1), Umetsu and Kurita [31] offered references of Nichols, et al. [35] and Takahashi [36], in which the emergence of Triprojectates was around the border between Santonian and Coniacian. However, some other studies reported the emergence age of triprojectates in the Turonian [37]. In addition, Tanaka and Hirano [38] also pointed out a possibility that the triprojectate pollen was firstly appeared in the East Asia and subsequently spread across the North Hemisphere. Thus, the emergence would have been much earlier. Furthermore, recently Legrand, et al. [13] investigated pollen composition of the outcrop of the bone bed. They did not find triprojectates, but found other pollens and spores that were not inconsistent with Turonian flora [13].

Some researchers inferred the age based on carbon isotope oscillation [30,33,34]. Although the oscillation fits the Coniasian to Santonian, it also fits the Late Turonian. Thus, it is not valid evidence indicating an accurate age. The $\mathrm{U}-\mathrm{Pb}$ age of the tuff overlaying the bone bed without hiatus nearly shows the single clustered peak, strongly indicating the accurate age of the bone bed.
Adocus kohaku is identified as a member of Adocidae based on the following characters [17]: (1) adocid-type of sculpturing, (2) narrow and shallow scute sulci, (3) weak ribheads, (4) weak rib thickenings of the costals, and (5) relatively long posterior plastral lobe $(>30 \%$ of plastron length). Adocus kohaku is assigned to the genus Adocus based on the marginals that overlap onto the costals in the middle and posterior parts of the carapace.

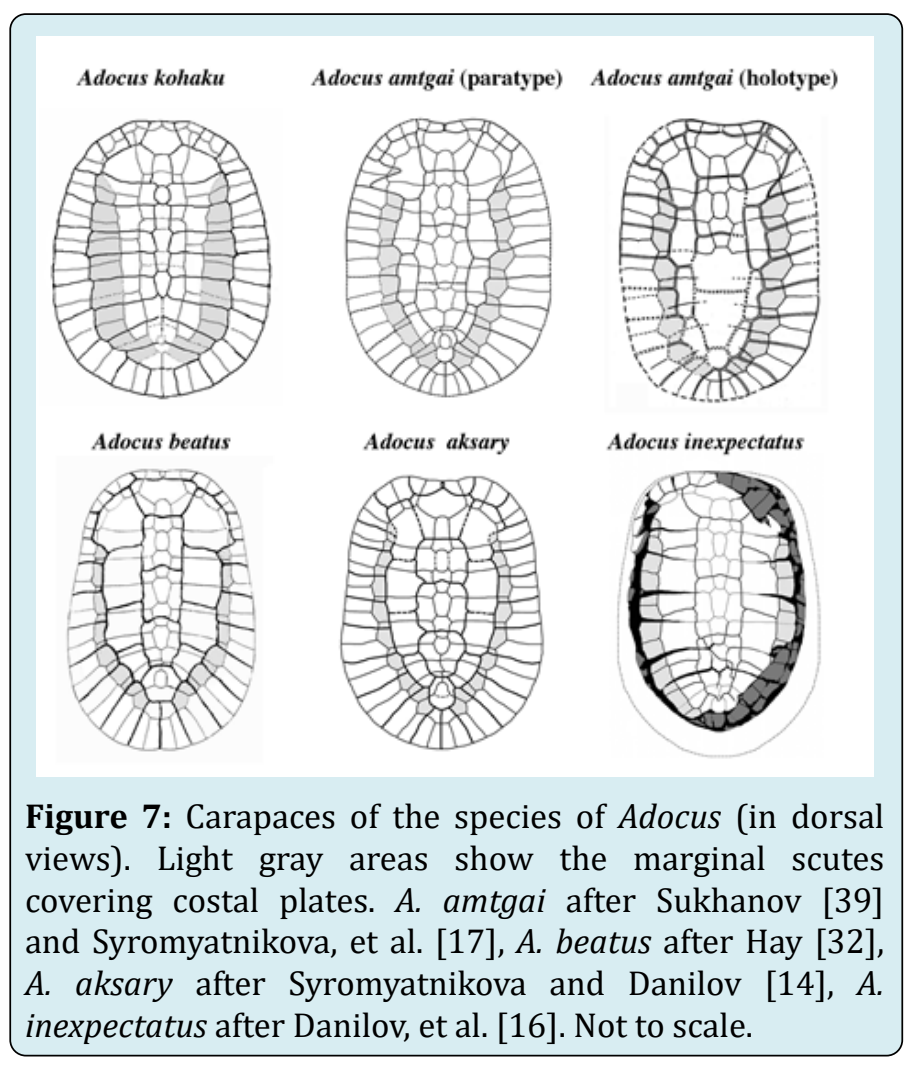




\section{International Journal of Paleobiology \& Paleontology}

Adocus are generally considered to be a fresh water aquatic turtle based on limb and shell morphology $[17,40]$. Cranial morphology suggests herbivorous feeding habitat like living Dermatemys mawii [40].

A. sengokuensis is thought to be the most basal species of this genus because of the presence of a wide cervical scute and its small size (carapace less than $30 \mathrm{~cm}$ long as estimated). Its geological age (late Barremian of the Early Cretaceous) is also the oldest among species of Adocus [19]. Other species of Adocus share the reduced cervical scute and larger size with shell up to at least $35 \mathrm{~cm}$ long.

The extension of the marginals onto the costals begin with the fourth (or third) marginals in A. aksary, A. amtgai, A. inexpectatus, and $A$. kohaku, taxa from the Late Cretaceous and Paleogene of Asia, whereas in other species of Adocus from North America and the Early Cretaceous of Asia it begins with fifth marginals as more basal state of this genus (Figure 6, Table 1) [17,19]. Thus, those taxa of Asian Adocus from the Late Cretaceous to Paleogene are considered to be a monophyletic group sharing additional marginal extension on costals [16]. In addition to the members of this derived clade, there are other more conservative and poorly known taxa of Adocus in Asia from the Late Cretaceous characterized by the overlapping of the marginals onto the costals beginning with the fifth marginal such as $A$. foveatus from the Santonian of Tajikistan, and A. kizylkumensis from the Cenomanian of Uzbekistan [14,17].
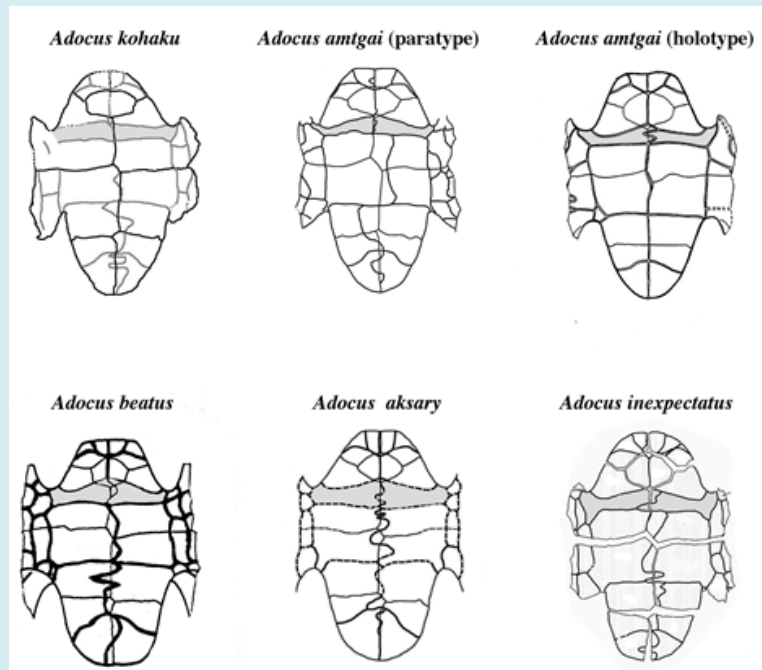

Figure 8: Plastra of the species of Adocus (in ventral views). Light gray areas show the pectoral scutes. A. amtgai after Sukhanov [39] and Syromyatnikova, et al. [17], A. beatus after Hay [32], A. aksary after Syromyatnikova and Danilov [14], A. inexpectatus after Danilov, et al. [16]. Not to scale.

\begin{tabular}{|c|c|c|c|c|c|c|c|c|}
\hline & $\begin{array}{c}A . \\
\text { sengokuensis }\end{array}$ & Adocus sp. & A. aksary & A. amtgai & A. kohaku & A. beatus & A. bossi & $\begin{array}{c}A . \\
\text { inexpectatus }\end{array}$ \\
\hline Locality & Japan & Japan & Uzbekistan & Mongolia & Japan & USA & USA & China \\
\hline Geological age & $\begin{array}{c}\text { Early } \\
\text { Cretaceous } \\
\text { (Barremian) }\end{array}$ & \begin{tabular}{|c|} 
Early \\
Cretaceous \\
(Aptian)
\end{tabular} & \begin{tabular}{c|} 
Late \\
Cretaceous \\
(Turonian)
\end{tabular} & $\begin{array}{l}\text { Early Late } \\
\text { Cretaceous }\end{array}$ & \begin{tabular}{|c|} 
Late \\
Cretaceous \\
(Turonian)
\end{tabular} & $\begin{array}{l}\text { Late Cretaceous } \\
\text { (Maastrichtian) }\end{array}$ & $\begin{array}{c}\text { Late } \\
\text { Cretaceous } \\
\text { (Maastrichtian) }\end{array}$ & $\begin{array}{c}\text { Paleogene } \\
\text { (Late Eocene) }\end{array}$ \\
\hline $\begin{array}{l}\text { Carapace } \\
\text { length }\end{array}$ & 29 & 37 & 40 & 40 & 60 & 50 & 70 & 35 \\
\hline Cervical scale & Wide & Narrow & Narrow & Narrow & Absent & Narrow & Narrow & Narrow \\
\hline $\begin{array}{c}\text { Second to } \\
\text { fourth pleurals }\end{array}$ & $\begin{array}{l}\text { Wide (width } \\
\text { makes up } \\
60 \% \text { of } \\
\text { length) }\end{array}$ & $\begin{array}{c}\text { Wide (width } \\
\text { makes up } \\
60 \% \text { of } \\
\text { length) }\end{array}$ & $?$ & $\begin{array}{l}\text { Narrow } \\
\text { (width } \\
\text { makes up } \\
30 \% \text { of } \\
\text { length) }\end{array}$ & $\begin{array}{l}\text { Narrow } \\
\text { (width } \\
\text { makes up } \\
30 \% \text { of } \\
\text { length) }\end{array}$ & $\begin{array}{c}\text { Wide (width } \\
\text { makes up } 60 \% \\
\text { of length) }\end{array}$ & $\begin{array}{c}\text { Wide (width } \\
\text { makes up } 60 \% \\
\text { of length) }\end{array}$ & \begin{tabular}{|} 
Wide (width \\
makes up \\
$60 \%$ of \\
length)
\end{tabular} \\
\hline $\begin{array}{c}\text { Marginals } \\
\text { overlapping on } \\
\text { to the costals }\end{array}$ & $\begin{array}{l}\text { Beginning } \\
\text { with fifth } \\
\text { marginal }\end{array}$ & $\begin{array}{l}\text { Beginning } \\
\text { with fifth } \\
\text { marginal }\end{array}$ & $\begin{array}{l}\text { Beginning } \\
\text { with third } \\
\text { or fourth } \\
\text { marginal }\end{array}$ & $\begin{array}{l}\text { Beginning } \\
\text { with fourth } \\
\text { marginal }\end{array}$ & $\begin{array}{c}\text { Beginning } \\
\text { with } \\
\text { fourth } \\
\text { marginal }\end{array}$ & $\begin{array}{l}\text { Beginning with } \\
\text { fifth marginal }\end{array}$ & $\begin{array}{l}\text { Beginning with } \\
\text { fifth marginal }\end{array}$ & $\begin{array}{c}\text { Beginning } \\
\text { with fourth } \\
\text { marginal }\end{array}$ \\
\hline $\begin{array}{c}\text { Width of } \\
\text { pleurals and } \\
\text { marginals on } \\
\text { costals }\end{array}$ & $\begin{array}{c}\text { Pleurals much } \\
\text { wider than } \\
\text { marginals }\end{array}$ & \begin{tabular}{|c|} 
Pleurals \\
much \\
wider than \\
marginals
\end{tabular} & $\begin{array}{c}\text { Pleurals } \\
\text { much } \\
\text { wider than } \\
\text { marginals }\end{array}$ & $\begin{array}{l}\text { Marginals } \\
\text { as wide as } \\
\text { pleurals }\end{array}$ & $\begin{array}{c}\text { Marginals } \\
\text { wider than } \\
\text { pleurals }\end{array}$ & $\begin{array}{c}\text { Pleurals much } \\
\text { wider than } \\
\text { marginal }\end{array}$ & $\begin{array}{c}\text { Pleurals much } \\
\text { wider than } \\
\text { marginal }\end{array}$ & $\begin{array}{c}\text { Pleurals much } \\
\text { wider than } \\
\text { marginal }\end{array}$ \\
\hline
\end{tabular}




\section{International Journal of Paleobiology \& Paleontology}

\begin{tabular}{|c|c|c|c|c|c|c|c|c|}
\hline $\begin{array}{c}\text { Extension of } \\
\text { gulars on to } \\
\text { entoplastron }\end{array}$ & $?$ & present & present & present & $\begin{array}{c}\text { absent or } \\
\text { present }\end{array}$ & $\begin{array}{c}\text { absent or } \\
\text { present }\end{array}$ & present & present \\
\hline $\begin{array}{c}\text { Pectorals } \\
\text { extension } \\
\text { on to the } \\
\text { entoplastron }\end{array}$ & present & present & present & present & absent & present & absent & present \\
\hline $\begin{array}{c}\text { Number of } \\
\text { inframarginals }\end{array}$ & $?$ & 4 pairs & $?$ & 3 or 5 pairs & 3 pairs & 4 pairs & 3 pairs & 4 pairs \\
\hline $\begin{array}{c}\text { Lateral } \\
\text { border of } \\
\text { Xiphiplastron }\end{array}$ & $?$ & Rounded & Rounded & $\begin{array}{c}\text { Nearly } \\
\text { straight }\end{array}$ & $\begin{array}{c}\text { Nearly } \\
\text { straight }\end{array}$ & Rounded & Rounded & Rounded \\
\hline
\end{tabular}

Table 2: Comparison of some species of Adocus in shell characters (after Syromyatnikova, et al. [17]; Danilov, et al. [16]; Sonoda, et al. [19], with modifications).?' denotes impossibility of measuring.

In all North American Adocus, the marginals primitively overlap onto the costals beginning with the fifth marginal as well. Nonetheless, Adocus from North America share relatively large size with at least a $50 \mathrm{~cm}$ long shell presumed as a synapomorphic character uniting them $[32,41]$. It seems apparent that the North American clade of Adocus originated from Asia during the early Late Cretaceous as suggested by both morphological analysis and the fossil record [19].

Adocus kohaku shares the additional more derived characters with $A$. amtgai; cervical scute highly reduced or lost; significantly wider fourth to twelfth marginals; very narrow second to fourth pleurals; the shorter of the pectorals. Therefore, A. kohaku and A. amtgai form an advanced clade within this genus (Figure 9). Adocus kohaku, however, has furthermore derived characters such as complete loss of cervical scute, wider marginal scutes on costal plates, and pectoral scute excluded from entoplastron (Figure 6). Additional remains of $A$. kohaku such as OSD 249 suggest this species had at least $60 \mathrm{~cm}$ long carapace, the largest among Adocus in Asia (Figure 5C). This large size is also considered as another derived state in A. kohaku. Thus, $A$. kohaku is the most advanced species of this genus, although its geological age (late Turonian) is rather early in the fossil record of Adocus. Such early occurrence of a derived taxon (A. kohaku) suggests early development of morphological diversifications within this genus. Similar, early diversification among Pan-Trionychia is also proposed in the family Nanhsiungchelyidae [42].

Occurrences of both most basal (A. sengokuensis) and most derived ( $A$. kohaku) taxa of this genus from Japan implies Eastern Asia was the center of early diversification of this group during the Cretaceous since the Early Cretaceous [2-5,43-50].

\section{Geological distribution and phylogeny of the genus Adocus}

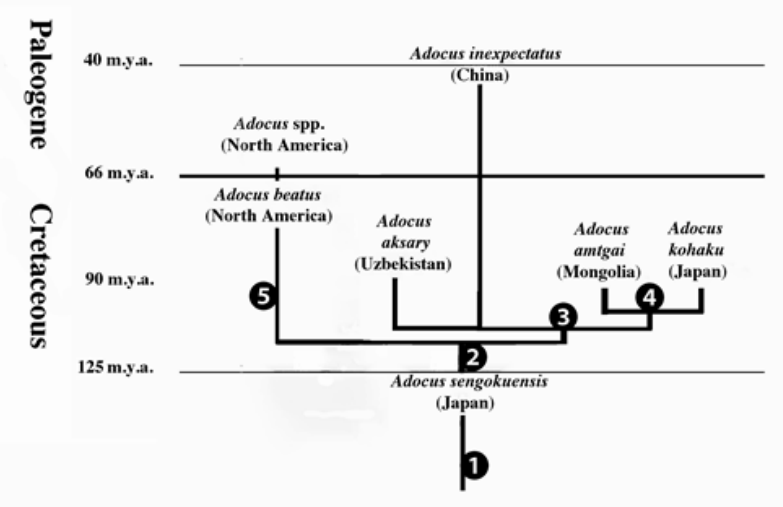

Figure 9: Geological distribution and phylogeny of the representative taxa of the genus Adocus. $1 \sim 5$ show the following synapomorphic characters at each node. 1, fifth to eleventh marginal scutes medially enlarged, overlying distal portion of costal plates; 2 , cervical scute reduced to much longer than wide; $\mathbf{3}$, fourth marginal scute overlaps onto the costal plates; 4 , pleural scutes are much longer than wide because of extreme expansion of marginals on the costal plates; 5, large size with carapace more than 50 cm long.

\section{Conclusion}

A nearly complete shell of the genus Adocus (Adocidae; Trionychia; Cryptodira; Testudines) was collected from the late Cretaceous (Turonian) Tamagawa Formation of Kuji Group at Kuji city, Iwate Prefecture, northeast Japan. This turtle shows unique features such as the loss of cervical scute, extreme expansion of marginal scutes overlying costal plates, exclusion of the humero-pectoral sulcus from entoplastron, and three pairs of inframarginals. Thus, A. kohaku is proposed 


\section{International Journal of Paleobiology \& Paleontology}

as a new species. Additional remains of $A$. kohaku suggest this species had carapace length of at least a $60 \mathrm{~cm}$ long, the largest among Adocus in Asia. As A. kohaku is a derived taxon within this genus, its occurrence in the early Late Cretaceous suggests early development of morphological diversifications within this genus, as previously proposed for the Nanhsiungchelyidae. Occurrences of both most basal ( $A$. sengokuensis) and most derived (A. kohaku) taxa from Japan implies eastern Asia was the center of diversification of this clade.

\section{Acknowledgement}

We are especially grateful to Kazuhisa Shikama (formerly undergraduate student of Waseda University) for collecting the holotype of the new species of the genus Adocus. We also thank to many colleagues, such as Masataka Yoshida, Ai Ito (University of Tokyo), and Masatoshi Okura (Konan City, Aichi, Japan), for kindly helping us during the paleontological excavations of the Tamagawa Formation. Yoichi Azuma (Fukui Prefectural Dinosaur Museum), Naoki Ikegami (Mifune Dinosaur Museum), Toshifumi Komatsu (Kumamoto University), and Manabu Kanou (Mikasa City Museum) for allowing access to comparative specimens. We especially thank I. G. Danilov (Zoological Institute, Russian Academy of Sciences), V. B. Sukhanov (Paleontological Institute, Moscow), and E. S. Gaffney (American Museum of Natural History) for their examination of comparative fossil turtles.

\section{References}

1. Kimura Y, Aizawa J, Sasaki K (2005) Sedimentation environment and diagenesis of the Koji area in Iwate prefecture. Scientific Reports of Fukuoka University 35(1): 31-40.

2. Hirayama R (2010) Non-marine turtles from the Early Cretaceous Tetori Group of Kasekikabe of Hakusan City, Ishikawa Prefecture, Central Japan. Hakusan City Board of Education, Ishikawa Prefecture, Japan, pp: 19-24.

3. Hirayama R, Kobayashi Y, Sonoda T, Sasaki K (2010) Preliminary report of terrestrial vertebrates from the Late Cretaceous Tamagawa Formation of the Kuji Group of Kuji, Iwate Prefecture, eastern Japan. Journal of Fossil Research 42: 74-82.

4. Hirayama R, Kobayashi Y, Sonoda T, Takisawa T, Sasaki $\mathrm{K}$ (2012) Late Cretaceous non-marine turtles (Class Reptilia: Order Testudines) from Kuji, Iwate Prefecture, northeastern Japan. The 11th Mesozoic Terrestrial Ecosystem, Program and Abstracts, pp: 59.

5. Hirayama R, Isaji S, Hibino T (2012) Kappachelys okurai gen. et sp. nov. a new stem soft-shelled turtle from the Early Cretaceous of Japan. In: Brinkman DB, Holroyd PA, Gardner JD, (Eds.), Morphology and Evolution of Turtles, Springer, Dordrecht, pp: 179-185.

6. Hirayama R, Takisawa T, Sasaki K, Sonoda T, Yoshida $M$, et al. (2015) Terrestrial vertebrates from the Late Cretaceous (Santonian) of Iwate Prefecture, eastern Japan. Society of Vertebrate Paleontology, pp: 143.

7. Hirayama R, Tsuihiji T, Okura $\mathrm{M}$, Uno $\mathrm{H}$, Takisawa $\mathrm{T}$ (2019) Tyrannosauroid tooth from the Late Cretaceous (Turonian) of northern Japan. Society of Vertebrate Paleontology, pp: 118.

8. Hirayama R, Uno H, Okura M, Takisawa T (2019) Large soft-shelled turtles (Order Testudines: Family Trionychidae) from the Late Cretaceous (Turonian) Tamagawa Formation, Kuji Group in Iwate Prefecture, Japan. Palaeontological Society of Japan, pp: 12.

9. Umetsu K, Hirayama R, Sonoda T, Takashima R (2013) Marine and nonmarine deposits of the Cretaceous Miyako and Kuji groups and Late Cretaceous terrestrial vertebrates in Iwate Prefecture, northeast Japan. Journal of Geological Society of Japan 119: 82-95.

10. Takekawa A, Hirayama R, Aoki R, Sasaki K, Takisawa T (2014) Crocodylomorpha from the Upper Cretaceous Tamagawa Formation of the Kuji Group, Iwate Prefecture, northeastern Japan. Society of Vertebrate Paleontology, pp: 238.

11. Takekawa A, Hirayama R, Aoki R, Sasaki K, Takisawa $\mathrm{T}$ (2015) Fossil Crocodyliformes from the Tamagawa Formation of Kuji Group. Paleontological Society of Japan, pp: 19.

12. Miyata S, Hirayama R, Nakajima Y, Maekawa Y, Okura M, et al. (2019) A preliminary report of elasmobranch fossils from the Upper Cretaceous Tamagawa Formation (Turonian-Santonian). Kuji Group, Iwate Prefecture, Northeast Japan. Journal of Fossil Research 51(2): 68-75.

13. Legrand J, Nishida N, Hirayama R (2019) Paleoenvironmental reconstruction from palynological analysis of the Upper Cretaceous Tamagawa Formation, Kuji Group, at the Osawada River locality (Kuji City, Iwate Prefecture, Japan). Journal of Fossil Research 51: 59-67.

14. Syromyatnikova EV, Danilov IG (2009) New Material and A Revision of Turtles of the Genus Adocus (Adocidae) From the Late Cretaceous of Middle Asia and Kazakhstan. Proceedings of the Zoological Institute the Russian Academy of Sciences 313(1): 74-94. 


\section{International Journal of Paleobiology \& Paleontology}

15. Danilov IG, Sukhanov VB, Syromyatnikova EV (2011) New Asiatic materials on turtles of the family Adocidae with a review of the adocid record in Asia. Proceedings of the Zoological Institute RAS 315(2): 101-132.

16. Danilov IG, Syromyatnikova EV, Skutschas PP, Kodrul TM (2013) The first 'true' Adocus (Testudines, Adocidae) from the Paleogene of Asia. Journal of Vertebrate Paleontology 33: 1071-1080.

17. Syromyatnikova EV, Danilov IG, Sukhanov VB (2013) The skeletal morphology and phylogenetic position of Adocus amtgai, an adocid turtle from the Late Cretaceous of Mongolia. Historical Biology 45: 155-173.

18. Hirayama R (2002) Preliminary report of the fossil turtles from the Kitadani Formation (Early Cretaceous) of the Tetori Group of Katsuyama, Fukui Prefecture, Central Japan. Memoir of the Fukui Prefectural Dinosaur Museum 1: 29-40.

19. Sonoda T, Hirayama R, Okazaki Y, Ando H (2015) A new species of the genus Adocus (Adocidae Testudines; Family Adocidae) from the Lower Cretaceous of Southwest Japan. Paleontological Research 19(1): 26-32.

20. Uno H, Mitsuzuka S, Horie K, Tsutsumi Y, Hirayama R (2018) U-Pb dating of turtle fossils from the Upper Cretaceous Tamagawa Formation in Kuji, Iwate, Japan. Turtle Evolution Symposium, program and abstracts, pp: 87.

21. Hirayama R, Kurihara K, Kanou M (2014) Fossil turtle from the Late Cretaceous Mikasa Formation in Mikasa, Hokkaido Prefecture, northern Japan. Palaeontological Society of Japan, pp: 20.

22. Otsuka K, Hirayama R, Isaji S, Manabe M, Matsumoto $\mathrm{R}$, et al. (2020) Preliminary report of vertebrate fossilbearing bed of the Kitadani Formation, Tetori Group in the Shiramine area, Hakusan City, Ishikawa Prefecture, Japan. Palaeontological Society of Japan, pp: 57.

23. Sano S (2018) Recent advances in the stratigraphy of the Upper Mesozoic Tetori Group in northern Central Japan: beyond the paradigm of Maeda (1961). Journal of Fossil Research 51: 5-14.

24. Sonoda T, Miyata K, Kubo T, Shibata M, Azuma Y, et al. (2014) Trionychoid turtles from the Upper Cretaceous Mitsuze Formation, Nagasaki Prefecture. Palaeontological Society of Japan, pp: 19.

25. Hirayama R (1998) Fossil turtles from the Mifune Group (Late Cretaceous) of Kumamoto Prefecture, Western Japan. In: Report of the research on the distribution of important fossils in Kumamoto Prefecture. Dinosaurs from the Mifune Group, Kumam, pp: 85-99.

26. Miyake $Y$, Aramaki M, Komatsu T, Hirayama R, Manabe $M$, et al. (2011) Vertebrate fossils and depositional environments of the Upper Cretaceous Himenoura Group in the Koshikijima Islands, Kagoshima, Japan. Palaeontological Society of Japan, pp: 18.

27. Tanai $\mathrm{T}$ (1979) Late Cretaceous Floras from the Kuji District, Northeastern Honshu, Japan. Journal of Faculty of Science, Hokkaido University 4th sem 19(1-2): 75136.

28. Terui K, Nagahama H (1995) Depositional facies and sequences of the Upper Cretaceous Kuji Group, Northeast Japan. Memoirs of Geological Society of Japan 45: 238249.

29. Chinzei K (1986) Shell structure, growth, and functional morphology of an elongate Cretaceous oyster. Palaeontology 29(1):139-154.

30. Arimoto J, Takashima R, Nishi H, Jyo S, Yamanaka T, et al. (2015) High-resolution stratigraphic correlation of the Upper Cretaceous Kuji Group based on carbon isotope stratigraphy and $\mathrm{U}-\mathrm{Pb}$ radiometric dating. Geological Society of Japan, pp: 66.

31. Umetsu K, Kurita Y (2007) Palynostratigraphy and age of the Upper Cretaceous Kuji Group. Journal of the Japanese Association for Petroleum Technology 72: 215-223.

32. Hay OP (1908) The fossil turtles of North America. Carnegie Institute of Washington 75: 1-568.

33. Nishi H, Takashima R, Jo S, Arimoto J, Yamanaka T, Orihashi Y, et al. (2015) Detailed age determination of Cretaceous shallow marine - non-marine strata. Abstract of Japan Geoscience Union Meeting MIS34-07, 301A.

34. Arimoto J, Takashima R, Nishi H, Yamanaka T, Orihashi Y, et al. (2018) Constraining the depositional age of an Upper Cretaceous non- marine and shallow marine siliciclastic succession, Kuji Group, northeastern Japan, based on carbon isotope stratigraphy and U-Pb radiometric dating. Cretaceous Research 92: 264-278.

35. Nichols DJ, Sweet AR (1993) Biostratigraphy of Upper Cretaceous nonmarine palynofloras in a north-south transect of the Western Interior Basin. In: Caldwell WGE, Kauffman EG, (Eds.), Evolution of the Western Interior Basin, Geological Association of Canada-Special Paper, Toronto 39: 539-584.

36. Takahashi K (1995) Diversification of Late Cretaceous angiosperm pollen in East Asia. Journal of Geological 


\section{International Journal of Paleobiology \& Paleontology}

Society of Japan 101(1): 70-78.

37. Farabee MJ (1993) Morphology of Triprojectate fossil pollen: Form and distribution in space and time. The Botanical Review 59: 211-249.

38. Tanaka S, Hirano H (2009) Angiosperm pollen fossils from the Upper Cretaceous in Hokkaido; diversification of angiosperm pollen during the Late Cretaceous in the Aqulapollenites province. Japanese Journal of Palynology 54(1): 5-14.

39. Sukhanov V B (2000) Mesozoic turtles of Middle and Central Asia. In: Benton M J, Shishkin MA, Unwin DM, Kurochkin EN, (Eds.), The Age of Dinosaurs in Russia and Mongolia, Cambridge University Press, Cambridge, pp: 309-367.

40. Meylan PA, Gaffney ES (1989) The skeletal morphology of the Cretaceous cryptodiran turtle, Adocus, and the relationships of the Trionychoidea. American Museum Novitates, pp: 1-60.

41. Gilmore CW (1919) Reptilian faunas of the Torrejon, Puerco, and underlying Upper Cretaceous formations of San Juan County, New Mexico. U S Geological Survey Professional Paper 119: 1-75.

42. Hirayama R, Sakurai K, Chitoku T, Kawakami G, Kito N (2001) Anomalochelys angulata, an unusual land turtle of Family Nanhsiungchelyidae (Superfamily Trionychoidea; Order Testudines) from the Upper Cretaceous of Hokkaido, North Japan. Russian Journal of Herpetology 8(2): 127-138.

43. Hirayama R (2005) New materials of non-marine turtles from the Early Cretaceous Tetori Group of former Shiramine-mura of Hakusan City, Ishikawa Prefecture, Central Japan. In: Scientific report on fossil animals of Kuwajima "Kaseki-kabe" (Fossil-bluff) from the Kuwajima Formation, Tetori Group, Hakusan, Ishikawa, Japan, Shiramine Village Board of Education, Ishikawa Prefecture, Japan, pp: 12-20.

44. Hirayama R, Brinkman DB, Danilov IG (2000) Distribution and biogeography of non-marine Cretaceous turtles. Russian Journal of Herpetology 7(3): 181-198.

45. AndoH (1997) Apparentstacking patterns ofdepositional sequences in the Upper Cretaceous hallow-marine to fluvial successions, Northeast Japan. Geological Society of Japan 48(85): 43-59.

46. Groecke DR, Hesselbo SP, Jenkins HC (1999) Carbonisotope composition of Lower Cretaceous fossil wood: ocean atmosphere-chemistry and relation to sea-level change. Geology 27(2): 155-158.

47. Kurita H, Matsuoka K, Obuse A (1997) Application of organic-walled microfossils (palynomorphs) to sedimentary environmental analyses. Journal of Sedimentological Society of Japan 44(4): 59-69.

48. Mitsuzuka S, Ando H (2015) Sedimentary faces and sequence stratigraphy of the Upper Cretaceous Kuji Group, northeast of water Prefecture, Japan. Geological Society of Japan, pp: 11.

49. Shoene B (2014) U-Th-Pb Geochronology. Treatise on Geochemistry 4: 341-378.

50. Danilov IG, Syromyatnikova EV (2008) New materials on turtles of the family Nanhsiungchelyidae from the Cretaceous of Uzbekistan and Mongolia, with a revision of the nanhsiungchelyid record in Asia. Proceedings of the Zoological Institute the Russian Academy of Sciences 312: 3-25. 